\title{
PENGARUH BAHAN BAKU DAN MANAJEAMEN RANTAI PASOKAN TERHADAP PROSES PRODUKSI PT. NIRO CERAMIC NASIONAL INDONESIA
}

\author{
Muhammad Yasman Suudi 1) \\ 1) Mahasiswa Program Studi Manajemen FE UNKRIS \\ Eddy Sanusi. $S^{2)}$ \\ 2) Dosen Program Studi Manajemen FE UNKRIS \\ Alamat: Kampus UNKRIS, Jatiwaringin Jakarta Timur \\ Email: eddy.sanusi23@gmail.com
}

\begin{abstract}
The aim of this study was to find out the raw of materials and supply chain management impact to company's production progress. Population from this research are employee production division of PT. Niro Ceramic Nasional Indonesia as more as 250 persons and sample used are 130 respondents. Research method used is quantitative method, analysis technique multiple regression and simple regression. The results of this study indicate that simultaneously the raw of materials and supply chain management 45,9\% from the progress of production. $31,7 \%$. and from the Raw of materials to production process $16,0 \%$ from the supply chain management to production process.
\end{abstract}

Keywords: Raw materials, supply chain management, and production process

\section{PENDAHULUAN}

Sebagaimana kita ketahui di dalam perusahaan terdapat tahapan proses produksi yang merupakan suatu cara, metode, ataupun teknik. Bagaimana penambahan manfaat atau penciptaan faedah baru, dilaksanakan dalam perusahaan. Oleh karena itu proses produksi merupakan salah satu kunci sukses untuk mencapai tingkat kualitas produk dengan adanya nilai tambah pada produk tersebut yang bisa memberikan nilai lebih pada perusahaan. Produk merupakan suatu barang atau jasa yang dikeluarkan dari hasil sebuah proses produksi atau hasil produksi ditawarkan kepada konsumen baik itu yang berwujud maupun yang tidak berwujud untuk memenuhi sebuah keinginan dan kebutuhan konsumen. Menurut Assauri (2016) "proses produksi merupakan suatu kegiatan yang melibatkan tenaga manusia, bahan, serta peralatan untuk menghasilkan produk yang berguna. Dengan aliran proses bahan mentah menjadi produk akhir dan urutan operasi yang digunakan untuk menghasilkan produk atau jasa selalu tetap". Dari uraian diatas dapat dilihat bahwa proses produksi pada hakikatnya dapat dikatakan sebagai proses pengubahan (transformasi) dari bahan atau kompenen (input) menjadi produk lain yang mempunyai nilai lebih tinggi atau dalam proses terjadi penambahan nilai. Sehingga dapat disimpulkan bahwa proses produksi merupakan kegiatan yang dilakukan oleh manusia untuk mengubah bahan baku menjadi produk jadi dengan melakukan beberapa tahapan. Menurut Assauri (2016) proses produksi dipengaruhi oleh beberapa indikator yaitu perencanaan produksi, jumlah yang dihasilkan, dan pengawasan. Adanya beberapa faktor pendukung dalam kelancaran proses produksi diantaranya faktor bahan baku, supply chain management, sumber daya alam, sumber daya manusia, modal, dan lain-lain.

Untuk menjaga kelancaran proses produksi, maka perusahaan harus menyediakan bahan baku yang cukup dan merencanakannya dari jauh-jauh hari sebelum proses produksi dimulai. Hal ini dilakukan agar dapat mengatur persediaan dalam tingkat yang tepat jumlah, 
mutu, waktu dan biaya yang rendah seperti yang diharapkan. Proses produksi yang diterapkan oleh perusahaan diharapkan dapat berjalan dengan lancar dan dapat mencapai suatu sasaran yang optimal dengan menggunakan sumber-sumber secara efektif dan efisien, selain itu tujuan dari sebuah kegiatan produksi adalah untuk memperoleh keuntungan. Bahan baku merupakan unsur paling aktif dalam sebuah perusahaan yang secara terus-menerus diperoleh dan diubah, kemudian dijual kembali. Bahan baku memiliki manfaat sebagai faktor produksi atau bahan olah yang kemudian dimasukan ke dalam sebuah proses produksi untuk dijadikan produk akhir. Adapun tujuan dari persediaan bahan baku adalah menjamin tersedianya bahan baku pada tingkat yang optimal agar proses produksi dapat berjalan sesuai dengan rencana pada tingkat biaya yang minimum serta kualitas produk yang tinggi. Menurut Ahyari (2012) bahan baku pada umumnya dapat berasal dari sumber alam secara langsung atau dari perusahaan lain dalam jumlah tertentu dimana selanjutnya akan dipergunakan untuk menunjang pelaksanaan proses produksi perusahaan. Bahan baku menurut Ahyari (2012) diukur oleh indikator-indikator yaitu perkiraan bahan baku, harga bahan baku, waktu tunggu. Pengaruh bahan baku terhadap proses produksi juga dapat dibuktikan melalui penelitian yang dilakukan oleh Yani (2017) dalam penelitian ini menghasilkan bahwa hasil pengujian hipotesis pertama ditemukan bukti empiris bahwa secara parsial, perencanaan kebutuhan bahan baku mempunyai pengaruh positif yang signifikan terhadap kelancaran proses produksi.

Selain penerapan bahan baku, ada faktor lain yang dapat menunjang dan mempengaruhi kelancaran proses produksi yaitu penerapan supply chain management. Dimana supply chain management itu sendiri sebagai pelaksana perencanaan dari sebuah proses produksi, semisal pembelian bahan baku di lakukan oleh supply chain management dengan operator purchasing. Menurut Haming dan Nurnajamuddin (2012) supply chain management adalah "proses perencanaan, penerapan, dan pengendalian operasi yang bertujuan untuk mencukupi kebutuhan pelanggan efisien mungkin". Supply chain managament diukur oleh indikator-indikator yaitu sebagai berikut kebutuhan, produksi, dan kerjasama (Haming dan Nurnajamuddin, 2012). Supply chain management terhadap proses produksi juga dapat dibuktikan melalui penelitian yang dilakukan Zulfahmi, et al (2018) menyatakan bahwa supply chain management sangat memungkinkan tercapainya peningkatan dalam proses produksi, serta dapat menghasilkan informasi terkait perencanaan produksi yang akan membantu kegiatan produksi.

Jadi, untuk menjaga kelancaran dalam proses produksi maka perlu diterapkan bahan baku, dan supply chain management terhadap proses produksi yang efektif dan efisien. Secara simultan bahan baku dan supply chain management secara bersama-sama memberikan pengaruh terhadap kelancaran proses produksi.

Tujuan penelitian ini adalah untuk mengetahui pengaruh bahan baku, dan supply chain management terhadap proses produksi PT. Niro Ceramic Nasional Indonesia.

\section{LANDASAN TEORI}

\section{Proses Produksi}

Proses produksi merupakan pusat pelaksanaan kegiatan yang konkret bagi pengadaan barang dan jasa pada suatu badan usaha dan perusahaan. Maka dari itu kelancaran pelaksanaan proses produksi merupakan suatu hal yang sangat diharapkan dalam setiap perusahaan. Menurut Assauri (2016), "proses produksi merupakan suatu kegiatan yang melibatkan tenaga manusia, bahan, serta peralatan untuk menghasilkan produk yang berguna". Teori diatas didukung oleh Gaspersz (2010) proses produksi adalah "integrasi dari metode kerja, informasi, material, tenga kerja, dan peralatan atau mesin dalam suatu 
lingkungan kompetitif di pasar. Proses produksi juga dapat mencerminkan kualitas dari perusahaannya, seberapa detail dan lancarnya proses produksi maka dapat dikatakan perusahaan sangat berkomitmen dengan apa yang mereka produksi".

Menurut Ahyari (2012) proses produksi yaitu teknik, metode, atau suatu cara tentang bagaimana kegiatan penciptaan fungsi baru atau penambahan faedah tersebut dilaksanakan. Teknik atau metode yang digunakan pun harus disesuaikan dengan produk apa yang akan dibuat oleh perusahaan agar kualitas yang dihasilkan dapat maksimal. Sedangkan menurut Yamit (2011) proses produksi adalah proses pengubahan (transformasi) dari bahan atau komponen (input) menjadi produk lain yang mempunyai nilai lebih tinggi atau dalam proses terjadi penambahan nilai (output). Menurut Gunawan (2016) produksi merupakan "suatu cara, pola, dan sistem untuk menciptakan atau menambah suatu manfaat barang atau jasa dengan menggunakan dari beberapa sumber seperti sumber daya manusia, uang, mesin, dan material yang ada". Menurut Irhami (2014) tentang proses produksi adalah sesuatu yang dihasilkan oleh suatu perusahaan baik bentuk barang (goods) maupun jasa (service) dalam suatu periode waktu yang selanjutnya dihitung sebagai nilai tambah bagi perusahaan. Sedangkan menurut Tampubolon (2014) proses produksi adalah kegiatan operasional yang mempergunakan peralatan produksi yang disusun dan diatur sedemikian rupa yang dapat dimanfaatkan secara fleksibel (multi purpose) untuk menghasilkan berbagai produk atau jasa.

Menurut Heizer dan Render (2015) mengatakan bahwa proses "juga diartikan sebagai cara, metode ataupun teknik bagaimana produksi itu dilaksanakan, jadi proses produksi adalah kegiatan untuk menambah kegunaan suatu barang dan jasa dengan menggunakan faktor produksi yang ada". Menurut Handoko (2012) proses produksi dapat dibedakan menurut dasar karakteristik aliran prosesnya atau atas tipe pesanan langganan. Ada tiga tipe proses produksi, antara lain: 1). Aliran garis yang memiliki ciri-ciri bahwa proses produksi dari bahan mentah sampai menjadi produk jadi menggunakan urutan operasi secara tetap dan produk pada sebelumnya telah distandartisasi dengan tepat. Pada aliran garis ada dua tipe produksi, amtara lain: a). Produksi masa yaitu memproduksi kumpulan produk secara besarbesaran dengan mengikuti serangkaian proses yang sama seperti sebelumnya atau langkah yang digunakan sama secara berulang-ulang dan serupa, dan b). Proses produksi terusmenerus. Proses produksi dilakukan pada waktu dalam kurun waktu yang lama karena hal ini bertujuan untuk menghindari penumpukan proses produksi pada satu titik, sehingga aliran produksinya berjalan terus dari satu operasi ke operasi selanjutnya, 2). Aliran Intermiten (job shop), perusahaan melakukan proses produksi yang sejenis dan pada waktu yang terputus-putus. Pada aliran ini, alat dan tenaga kerja telah diatur dan disesuaikan pada stasiun kerja yang telah ditetapkan. Aliran ini juga menggunakan peralatan serbaguna sehingga mengurangi risiko apabila terjadi perubahan yang berkaitan dengan produk yang akan diproduksi. Akan tetapi, aliran ini dapat menimbulkan kesulitan dalam pengendalian persediaan, penjadwalan produksi dan juga kualitas produk, dikarenakan pola aliran yang dimiliki aliran ini bercampur, dan 3). Proyek merupakan bentuk dari operasi yang digunakan dalam memproduksi produk khusus dan unik. Dalam proyek ini tidak ada aliran produk tetapi terdapat rangkaian urutan operasi. Masalah yang muncul pada proyeksi adalah perencanaan, penjadwalan, dan juga pengawasan kegiatan yang mengarah pda tahap penyelesaian proyek. Dari uraian diatas proses produksi dapat dimaknai sebagai suatu aktifitas atau kegiatan dimana terjadinya suatu perubahan proses atau transformasi dengan adanya beberapa faktor pendukung dalam kelancaran produksi diantaranya faktor bahan baku, supply chain management, sumber daya alam, sumber daya manusia, modal, dan lainlain, atau produksi adalah proses input (bahan baku) menjadi output (barang atau jasa) yang mempunyai nilai ekonomi lebih. 
Kegiatan proses produksi yang baik dan efektif terlebih dahulu harus disusun perencanaan yang baik mencakup beberapa faktor produksi yang dibutuhkan dalam melaksanakan proses produksi agar tidak terlalu banyak ataupun tidak terlalu sedikit serta langkah yang dilakukan untuk mencapai tujuan, kemudian diikuti dengan pengendalian terhadap pelaksanaan perencanaan sebelumnya. Dalam pelaksanaan proses produksi dan operasi ada tanggung jawab yang harus dilaksanakan diantaranya yaitu proses, kapasitas, persediaan, tenaga kerja, dan kualitas. Secara umum proses produksi terkait dengan pertanggungjawaban dalam pengolahan dan pengubahan masukan menjadi keluaran yang berupa barang jadi atau jasa dan nantinya akan dapat memberikan keuntungan bagi perusahaan. Menurut Assauri (2016) ada beberapa indikator dalam proses produksi yaitu sebagai berikut: 1). Perencanaan produksi. 2). Jumlah yang dihasilkan. 3). Pengawasan. 4). Mutu barang.

\section{Bahan Baku}

Peranan bahan baku didalam perusahaan sangat penting terutama dalam menunjang kelangsungan proses produksi, walaupun ada faktor-faktor lain yang penting tetapi persediaan bahan baku akan sangat berpengaruh terhadap pelaksanaan proses produksi. Bahan baku adalah benda yang dapat dibuat sesuatu, atau barang yang dibutuhkan untuk membuat sesuatu. Perusahaan selalu menghendaki jumlah bahan (persediaan) yang cukup agar proses produksi tidak terganggu. Menurut Ahyari (2012) bahan baku pada umumnya dapat berasal dari sumber alam secara langsung atau dari perusahaan lain dalam jumlah tertentu dimana selanjutnya akan dipergunakan untuk menunjang pelaksanaan proses produksi perusahaan. Dengan kondisi seperti itu, maka bahan baku yang sudah dibeli oleh perusahaan tetapi belum dipergunakan untuk proses produksi akan masuk sebagai persediaan bahan baku dalam perusahaan tersebut. Teori diatas didukung oleh Handoko (2012) "Persediaan bahan mentah (raw material) Persediaan barang-barang berwujud seperti baja, kayu, dan komponen-komponen lainnya yang digunakan dalam proses produksi. Bahan mentah dapat diperoleh dari sumber-sumber alam atau dibeli dari para pemasok atau dibuat sendiri oleh perusahaan untuk digunakan dalam proses produksi selanjutnya".

Sedangkan bahan baku menurut Herjanto (2010) "Persediaan bahan baku (Raw Material), persediaan ini adalah persediaan bahan baku mentah yang akan diproses dalam proses produksi”. Heizer dan Render (2015) menyatakan persediaan bahan mentah (raw material inventory) adalah bahan-bahan yang telah dibeli tetapi belum diproses. Bahanbahan dapat diperolah dari sumber alam atau dibeli dari supplier (penghasil bahan baku). Menurut Assauri (2016) "Bahan baku merupakan faktor penting yang ikut menentukan tingkat harga pokok dan kelancaran proses produksi usaha. Pengertian bahan baku merupakan barang-barang yang akan menjadi bagian dari produk jadi yang dengan mudah dapat diikuti biayanya. Menurut Santoso (2010) "bahan baku (raw material) yaitu bahan baku yang akan diproses lebih lanjut dalam proses produksi".

Menurut Ramdhani (2014) "bahan baku merupakan barang-barang yang diperoleh untuk digunakan dalam proses produksi, beberapa bahan baku diperoleh secara langsung dari sumber-sumber alam, bahan baku juga dapat diperoleh dari perusahaan lain". Bahan yang digunakan produksi dibedakan dalam 2 golongan, yaitu bahan baku langsung dan bahan baku tidak langsung. Bahan baku langsung mempunyai ciri yaitu: 1). Mudah ditelusuri ke produk selesai, 2). Merupakan bahan baku utama produk selesai, 3). Dapat diidentifikasi langsung ke proses produksi setiap produk. Bahan baku tidak langsung adalah selain bahan baku langsung yang digunakan dalam proses produksi dan biaya ini dipandang sebagai biaya overhead. Bahan baku faktor utama proses produksi yang sangat penting, 
karena kekurangan bahan baku dapat menghambat proses produksi, sebaliknya jika bahan baku terlalu besar maka akan membuat kerugian untuk perusahaan. Disamping itu juga bahan baku merupakan barang yang tidak bisa tahan lama, maka penyimpanan yang terlalu lama akan mengakibatkan resiko yang makin besar dan juga menambah kerugian bagi perusahaan.

Bahan baku merupakan faktor penting dalam menentukan tingkat harga pokok serta kelancaran proses produksi usaha. Ketersediaan bahan baku yang berkualitas akan mempengaruhi kelancaran proses produksi, apabila terjadi kekurangan bahan baku maka hal tersebut akan menghambat kegiatan proses produksi. Dalam penyelenggaraan persediaan bahan baku untuk pelaksanaan proses produksi dari suatu perusahaan, terdapat beberapa faktor yang akan mempengaruhi, dimana faktor-faktor tersebut saling berhubungan satu dengan yang lain.

Menurut Ahyari (2012) indikator-indikator bahan baku yaitu sebagai berikut: $1)$. Perkiraan bahan baku. 2). Harga bahan baku. 3). Waktu tunggu.

\section{Manajemen Rantai Pasokan}

Peranan manajemen rantai pasokan (supply chain management) didalam perusahaan juga sangat penting terutama dalam menunjang kelangsungan proses produksi, walaupun ada faktor-faktor lain yang penting tetapi manajemen rantai pasokan akan sangat berpengaruh terhadap pelaksanaan produksi. Menurut Haming dan Nurnajamuddin (2012) manajemen rantai pasokan adalah "proses perencanaan, penerapan, dan pengendalian operasi yang bertujuan untuk mencukupi kebutuhan pelanggan efisien mungkin". Teori diatas didukung oleh Heizer dan Render (2015) manajemen rantai pasokan "menggambarkan koordinasi dari keseluruhan kegiatan rantai pasokan, dimulai dari proses bahan baku dan diakhiri sampai ke pelanggan untuk mendapatkan hasil yang puas". Dengan rantai pasokan mencakup pemasok, perusahaan manufaktur atau penyedia jasa, dan perusahaan distributor, grosir, atau pengecer yang mengantarkan produk atau jasa ke konsumen akhir yang bertujuan untuk mengoordinasi kegiatan dalam memaksimalkan keunggulan kompetitif, dan manfaat bagi konsumen. Fitur utama dari rantai pasokan yang sukses adalah anggota-anggotanya yang berperan demi kepentingan timnya (rantai pasokan).

Sedangkan menurut Tampubolon (2014) manajemen rantai pasokan yaitu "sebagai perangkat pendekatan yang digunakan secara efisien untuk mengintegrasikan pemasok, produsen, serta gudang di intergrasikan dengan toko-toko untuk meminimalkan waktu yang tepat serta jangkauan sistem dengan biaya sesuai persyaratan tingkat pelayanan, sehingga barang yang diproduksi dapat di distribusikan ke lokasi dengan waktu yang tepat". Menurut Martono (2015) manajemen rantai pasokan merupakan "sistem terintegrasi yang mengkoordinasikan keseluruhan proses perencanaan (plan), sumber input bagi proses (source) pengiriman bahan mentah dari pemasok, proses transformasi input menjadi output transportasi, distribusi, pergudangan (deliver), sistem informasi dan pembayaran produk atau jasa, di organisasi atau perusahaan dalam mempersiapkan dan menyampaikan produk atau jasa kepada konsumen, serta layanan pengembalian produk atau jasa (return)".

Menurut Sumarsan (2013) manajemen rantai pasokan adalah "sekumpulan aktivitas dalam bentuk fasilitas yang terlibat dalam proses produksi dan distribusi barang mulai dari bahan baku, sampai produk jadi dan ketangan konsumen akhir. Proses tersebut terdiri dari perusahaan yang mengangkat bahan baku dari alam, pabrik yang memproduksi bahan baku menjadi bahan yang setengah jadi, pabrik yang memproduksi barang setengah jadi menjadi barang jadi dan mendistribusikan barang jadi ke konsumen akhir". Menurut Widjaja (2012) manajemen rantai pasokan merupakan "intergrasi aktivitas pengadaan barang dan pelayanan, pengubahan menjadi barang setengah jadi dan produksi akhir, serta pengiriman 
kepelanggan. Seluruh aktivitas ini mencangkup pembelian dan pengalihdayaan serta ditambah fungsi lain yang penting bagi hubungan antara pemasok dan distributor". Menurut Sahaya (2013) manajemen rantai pasokan yaitu "suatu konsep atau mekanisme untuk meningkatkan produktivitas seluruh perusahaan yang tergabung dalam rantai pasok melalui optimalisasi kualitas dan waktu, yang merupakan fungsi bisnis yang vital untuk mengkoordinasi pengelolaan aliran barang dan merupakan kunci kompetisi”.

Tujuan dari manajemen rantai pasokan menurut Heizer dan Render (2015) yaitu untuk mengkoordinasi kegiatan dalam rantai pasokan untuk memaksimalkan keunggulan kompetitif dan manfaat dari rantai pasokan bagi konsumen akhir.

Manfaat dari manajemen rantai pasokan menurut Sahaya (2013) yaitu: Meminimalkan inventory; Kegiatan manajemen rantai pasokan dapat menekan tingkat inventory, melalui pengendalian dan informasi intensif. 2). Mengurangi biaya; Pengintegrasian aliran produk dari pemasok sampai konsumen akhir dapat mengurangi biaya. 3). Mengurangi lead time; Koordinasi, sistem, data dan informasi yang tepat dalam pelaksanaan aliran barang dapat mengurangi lead time pengadaan, produksi dan distribusi. 4). Meningkatkan pendapatan; Konsumen yang setia dan menjadi mitra perusahaan dapat meningkatkan pendapatan perusahaan. 5). Ketepatan waktu penyerahan; Sistem aliran barang terintegrasi dan terkontrol, dapat menghasilkan penyerahan barang tepat waktu. 6). Menjamin kelancaran aliran barang; Pengintegrasian semua elemen manajemen rantai pasokan melalui sistem informasi, dapat memperlancar aliran barang. 7). Menjamin kualitas; Kualitas bahan baku dan hasil produksi barang jadi akan terjamin karena sejak awal sudah dikendalikan. 8). Menghindari kehabisan persediaan (stock out); Sistem kemitraan dengan supplier serta informasi intensif menghasilkan tingkat persediaan optimal. 9). Meningkatkan akurasi peramalan kebutuhan; Berdasarkan data dan informasi yang akurat maka tingkat peramalan kebutuhan menjadi lebih akurat. 10). Kepuasan konsumen; Kualitas produk dan layanan yang baik menjadikan konsumen setia dan yakin terhadap produk. 11). Mengurangi jumlah pemasok; Pemasok terbatas yang kompeten dapat mengurangi biaya, keragaman dan memudahkan pelacakan (tracking). 12 ). Mengembangkan kemitraan (partnership); Kerjasama jangka panjang, mempunyai tujuan yang sama dan saling percaya serta berbagi resiko. 13). Peningkatan kompetensi sumber daya manusia; Kompetensi sumber daya manusia akan semakin meningkat baik pengetahuan maupun keterampilan dalam penggunaan teknologi tinggi. 14). Perusahaan semakin berkembang; Perusahaan yang mendapatkan keuntungan akan menjadi besar dan berkembang. 15). Meningkatkan daya saing; Jaringan manajemen rantai pasokan yang berhasil dan nilai supply chain yang meningkat, secara otomatis akan meningkatkan daya saing perubahan.

Manajemen rantai pasokan merupakan salah satu faktor penting dalam kelancaran proses produksi. Keberhasilan dalam penerapan manajemen rantai pasokan akan mempengaruhi kelancaran proses produksi, apabila pelaksanaannya tidak maksimal maka akan menghambat kegiatan proses produksi. Menurut Haming dan Nurnajamuddin (2015) ada beberapa indikator dalam manajemen rantai pasokan yaitu sebagai berikut:

1). Kebutuhan. 2). Produksi. 3). Kerjasama.

\section{METODE PENELITIAN}

Penelitian ini dilaksanakan di PT. Niro Ceramic Nasional Indonesia yang berlokasi di daerah Jl. Mercedez, Desa: Cicadas, Kecamatan: Gunung Putri, Kabupaten Bogor. Populasinya adalah seluruh karyawan bagian produksi dari PT. Niro Ceramic Nasional Indonesia yang berjumlah 250 orang. Pengukuran atau menentukan jumlah sampel dalam penelitian ini menggunakan rumus Isaac dan Michael. (Sugiyono, 2015). 
Penelitian ini menggunakan metode teknik probability sampling. Dalam teknik probability sampling digunakan simple random sampling. Jumlah sampel dalam penelitian ini sebesar 130 (seratus tiga puluh) karyawan bagian produksi. Pengumpulan data dilakukan dengan penyebaran kuesioner secara tertutup. Teknik analisis data menggunakan analisis kuantitatif, dengan melakukan uji instrument data, uji asumsi, regresi linier berganda dan sederhana.

\section{HASIL PENELITIAN DAN PEMBAHASAN}

\section{Uji Instrumen Data}

Berdasarkan uraian tersebut di atas, maka untuk dapat menentukan apakah variabel bahan baku dan manajemen rantai pasokan dapat dijadikan pengukur terhadap proses produksi PT. Niro Ceramic Nasional Indonesia. Namun sebelumnya data diolah terlebih dahulu dan dilakukan pengujian terhadap variabel yang digunakan yaitu bahan baku manajemen rantai pasokan dan proses produksi untuk mengetahui apakah data tersebut akurat dan dapat dipercaya.

\section{Uji Validitas}

Pengujian validitas ini dilakukan untuk menguji apakah tiap butir pernyataan telah mewakili indikator yang akan diteliti, persyaratan minimum untuk dapat dikatakan valid adalah $\mathrm{r}=0,30$. Jadi, apabila korelasi antara butir-butir item pernyataan dengan skor total kurang dari 0,30 , maka butiran dalam instrumen tersebut dapat dikatakan tidak valid. Uji validitas dilakukan dengan melihat korelasi antara skor masing-masing item pernyataan dengan skor total. Dari perhitungan koefisien korelasi skor tiap butir pernyataan dari 130 responden tentang instrument proses produksi, dengan jumlah 13 pernyataan; instrumen bahan baku 12 pernyataan dan instrumen manajemen rantai pasokan 12 pernyataan dengan total skor setiap responden diperoleh hasil t hitung lebih besar dari $r$ kritis 0,300 .

Berdasarkan uji validitas dapat dinyatakan bahwa dari semua butir pernyataan variabel proses produksi, bahan baku dan manajemen rantai pasokan hasilnya adalah valid. pernyataan variabel proses produksi, bahan baku dan manajemen rantai pasokan hasilnya adalah valid.

\section{Uji Reliabilitas}

Pengujian reliabilitas ini dilakukan untuk menguji seberapa jauh hasil pengukuran yang dapat diandalkan secara konsisten. Pada tabel hasil pengujian reliabilitas berikut, diketahui bahwa semua variabel mempunyai alpha di atas 0.6 yang berarti bahwa semua variabel dalam penelitian ini dapat diandalkan.

Tabel 1: Hasil Uji Reliabilitas Variabel

\begin{tabular}{lcc}
\hline \multicolumn{1}{c}{ Variabel } & Cronbach's Alpha & Keterangan \\
\hline Proses Produksi & 0.722 & Reliabel \\
Bahan Banu & 0.767 & Reliabel \\
Supply Chain Mgt & 0.698 & Reliabel \\
\hline
\end{tabular}

Sumber: Hasil pengolahan data, 2020

Berdasarkan Tabel 1, dapat dinyatakan bahwa nilai Cronbach's Alpha positif dimana lebih besar dari 0.6 yang merupakan batas minimal koefisien reliabilitas dapat dianggap baik. Dengan demikian, bahwa pernyataan di atas reliabel. 


\section{Uji Asumsi Klasik}

Tujuan dari pengujian asumsi klasik ini adalah untuk memberikan kepastian bahwa persamaan regresi yang didapat memiliki ketepatan dalam estimasi dan konsisten.

\section{Hasil Uji Normalitas}

Berdasarkan hasil uji normalitas data dengan menggunakan metode KolmogorovSmirnov didapatkan hasil signifikansi sebesar 0.200 yang berarti > dari 0.05. Maka distribusi dari metode Kolmogorov - Smirnov adalah berdistribusi normal.

\section{Hasil Uji Multikolinieritas}

Berdasarkan hasil perhitungan didapat nilai tolerance value sebesar 0.998 , nilai VIF sebesar 1.002. Maka uji multikolinieritas data dikatakan bebas atau tidak terjadi multikolinieritas karena nilai Tolerance value $0.998>0.10$ atau nilai VIF $1.002<10$.

\section{Hasil Uji Heteroskedastisitas}

Cara untuk mendeteksi ada atau tidaknya heteroskedastisitas yaitu dengan cara melihat grafik scatterplot dasar analisisi yaitu dengan ketetntuan sebagai berikut: 1). Jika ada pola tertentu, seperti titik-titik yang ada membentuk pola tertentu yang teratur (bergelombang, melebar, kemudian menyempit) maka data teridentifikasikan telah terjadi heteroskedastisitas. 2). Jika tidak ada pola yang jelas, serta titik-titik menyebar di atas dan dibawah angka 0 pada sumbu Y, maka tidak terjadi heteroskedastisitas.

Hasil pengujian terlihat pada gambar dibawah ini.

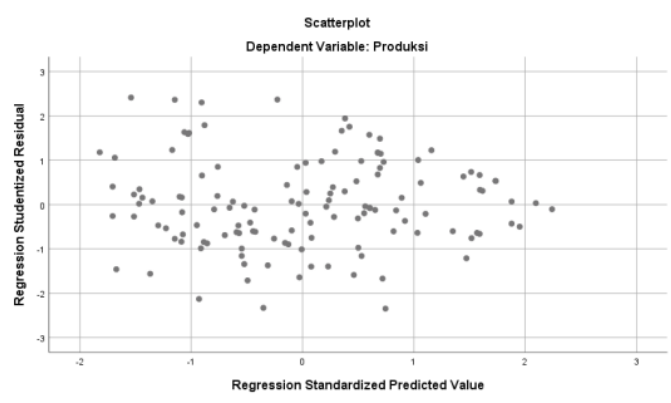

\section{Gambar 1. Hasil Scatter Plot Uji Heteroskedastisitas}

Pada gambar grafik scatterplots, terlihat bahwa titik-titik menyebar secara acak baik tersebar diatas maupun dibawah angka 0 pada sumbu Y. Dengan hasil ini dapat disimpulkan bahwa Jika tidak ada pola yang jelas, serta titik-titik menyebar di atas dan dibawah angka 0 pada sumbu Y, maka data tersebut bisa dikatakan tidak terjadi heteroskedastisitas.

\section{Analisis Regresi Linier Berganda}

Tabel 2: Pengaruh Bahan Baku dan Manajemen Rantai Pasokan Terhadap Proses Produksi PT. Niro Ceramic Nasional Indonesia 


\begin{tabular}{|c|c|c|c|c|c|}
\hline $\begin{array}{c}\text { Hubungan } \\
\text { Variabel }\end{array}$ & R Square & Konstanta & Koef. B & Sig. & $\alpha$ \\
\hline $\begin{array}{l}\text { Bahan Baku } \\
\text { Min Rantai Pasokan }\end{array}$ & 0.459 & 6.763 & $\begin{array}{l}0.535 \\
0.406\end{array}$ & $\begin{array}{l}0.000 \\
0.000\end{array}$ & 0.05 \\
\hline
\end{tabular}

Pengujian Signifikansi

F hitung $>$ F tabel $=53.795>3.068$

Keterangan: Variabel Proses Produksi

Sumber: data diolah 2020

Berdasarkan Tabel 2, Nilai F hitung > F tabel $(53.795>3.068)$, maka Ho tolak, Ha terima, artinya ada pengaruh yang positif dan signifikan bahan baku dan manajemen rantai pasokan terhadap proses produksi PT. Niro Ceramic Nasional Indonesia. Nilai koefisien determinasi $\left(\mathrm{R}^{2}\right)$ sebesar 0.459 , artinya bahan baku dan manajemen rantai pasokan secara bersama-sama memberikan kontribusi sebesar 45,9\% kepada proses produksi PT. Niro Ceramic Nasional Indonesia, sedangkan sisanya sebesar 54,1\% disumbangkan faktor lain yang tidak dibahas dalam penelitian ini.

Persamaan Regresi $\mathrm{Y}=6.763+0.535\left(\mathrm{X}_{1}\right)+0.406\left(\mathrm{X}_{2}\right)$

Bahan baku dan manajemen rantai pasokan berpengaruh positif dan signifikan terhadap proses produksi PT. Niro Ceramic Nasional Indonesia pada tingkat nyata $95 \%$. Koefisien bahan baku sebesar 0,535 satuan, artinya jika ada peningkatan bahan baku, maka proses produksi PT. Niro Ceramic Nasional Indonesia akan meningkat atau sebaliknya dengan asumsi manajemen rantai pasokan tidak berubah. Koefisien manajemen rantai pasokan sebesar 0,406, artinya jika ada peningkatan manajemen rantai pasokan, maka proses produksi PT. Niro Ceramic Nasional Indonesia akan meningkat atau sebaliknya, dengan asumsi bahan baku tidak berubah.

\section{Analisis Regresi Linier Sederhana}

Tabel 3: Pengaruh Bahan Baku Terhadap Proses Produksi PT. Niro Ceramic Nasional Indonesia

\begin{tabular}{lccccc}
\hline \multirow{2}{*}{ Variabel } & \multicolumn{5}{c}{ Parameter } \\
\cline { 2 - 6 } & \multicolumn{7}{c}{ R Square } & Konstanta & Koef. B & Sig. & $\boldsymbol{\alpha}$ \\
\hline Bahan Baku & 0.317 & 22.961 & 0.551 & 0.000 & 0.05 \\
\hline Pengujian Signifikansi & & & & \\
\hline t hitung $>$ t tabel $=7.700>1.979$ & & & \\
\hline
\end{tabular}

Keterangan: Variabel Proses Produksi

Sumber: data diolah 2020

Berdasarkan Tabel 3, nilai koefisien determinasi $\left(\mathrm{R}^{2}\right)$ sebesar 0.317 , artinya bahan baku memberikan kontribusi sebesar $31,7 \%$ kepada proses produksi PT. Niro Ceramic Nasional Indonesia, sedangkan sisanya sebesar 68,3\% disumbangkan faktor lain yang tidak diteliti.

Persamaan Regresi $\mathrm{Y}=22.961+0.551\left(\mathrm{X}_{1}\right)$

Bahan baku berpengaruh positif dan signifikan pada tingkat nyata $95 \%$ terhadap proses produksi PT. Niro Ceramic Nasional Indonesia. Koefisien bahan baku sebesar 0,551 satuan, 
artinya jika ada peningkatan bahan baku, maka proses produksi PT. Niro Ceramic Nasional Indonesia akan meningkat atau sebaliknya.

Nilai thitung $>\mathrm{t}$ tabel $(7.700>1.979)$, maka Ho tolak, Ha terima, artinya ada pengaruh yang positif dan signifikan bahan baku terhadap proses produksi PT. Niro Ceramic Nasional Indonesia.

Tabel 5: Pengaruh Manajemen Rantai Pasokan Terhadap Proses Produksi PT. Niro Ceramic Nasional Indonesia

\begin{tabular}{lrrrrr}
\hline \multirow{2}{*}{ Variabel } & R Square & Konstanta & Koef. B & Sig. & $\boldsymbol{\alpha}$ \\
\cline { 2 - 7 } & 0.160 & 29.200 & 0.431 & 0.000 & 0.05 \\
\hline Mjn Rantai Pasokan & & & & & \\
\hline Pengujian Signifikansi & & & & \\
\hline t hitung > t tabel $=4.938>1.979$ &
\end{tabular}

Keterangan: Variabel Proses Produksi

Sumber: data diolah 2020

Berdasarkan Tabel 4, nilai koefisien determinasi $\left(\mathrm{R}^{2}\right)$ sebesar 0.160 , artinya manajemen rantai pasokan memberikan kontribusi sebesar $16,0 \%$ kepada proses produksi PT. Niro Ceramic Nasional Indonesia, sedangkan sisanya sebesar 74.0\% disumbangkan faktor lain yang tidak diteliti.

Persamaan Regresi Y $=29.200+0.431\left(\mathrm{X}_{1}\right)$

Manajemen rantai pasokan berpengaruh positif dan signifikan pada tingkat nyata $95 \%$ terhadap proses produksi PT. Niro Ceramic Nasional Indonesia. Koefisien manajemen rantai pasokan sebesar 0,431 satuan, artinya jika ada peningkatan manajemen rantai pasokan, maka proses produksi PT. Niro Ceramic Nasional Indonesia akan meningkat atau sebaliknya.

Nilai thitung > t tabel $(4.938>1.979)$, maka Ho tolak, Ha terima, artinya ada pengaruh yang positif dan signifikan manajemen rantai pasokan terhadap proses produksi PT. Niro Ceramic Nasional Indonesia.

\section{Pembahasan}

\section{Pengaruh Bahan Baku dan Manajemen Rantai Pasokan Terhadap Proses Produksi PT. Niro Ceramic Nasional Indonesia}

Berdasarkan hasil analisis diketahui bahwa bahan baku dan manajemen rantai pasokan dapat mendorong peningkatan proses produksi PT. Niro Ceramic Nasional Indonesia. Hal ini dapat dikatakan bahwa adanya penerapan bahan baku dan manajemen rantai pasokan akan dapat meningkatkan proses produksi pada PT. Niro Ceramic Nasional Indonesia Hasil penelitian ini sama dengan hasil penelitian yang dilakukan oleh Tahwin, et al, (2016), yaitu menganalisis pengaruh bahan baku dan manajemen rantai pasokan terhadap proses produksi. Dengan demikian hipotesis pertama diterima.

\section{Pengaruh Bahan Baku Terhadap Proses Produksi PT. Niro Ceramic Nasional Indonesia}

Hasil penelitian ini menunjukkan bahwa penerapan bahan baku yang sesuai dapat mendorong peningkatan proses produksi. Hal ini dikarenakan bahwa bahan baku memiliki keuanggulan, manajemen merencanakann persediaan bahan baku dengan benar, penggunaan bahan baku merupakan tanggung jawab karyawan, dan penggunaannya harus sesuai dengan 
SOP. Hasil penelitian ini sesuai dengan penelitian yang dilakukan oleh Yani (2017), yaitu menganalisis pengaruh bahan baku terhadap proses produksi. Dengan demikian hipotesis kedua diterima.

\section{Pengaruh Manajemen Rantai Pasokan Terhadap Proses Produksi PT. Niro Ceramic Nasional Indonesia}

Hasil penelitian ini menunjukkan bahwa manajemen rantai pasokan dapat mendorong peningkatan proses produksi. Hal ini dikarenakan bahwa manajemen rantai pasokan mengidentifikasi terhadap kebutuhan produksi, memastikan kedatangan persediaan bahan baku terjadwal sesuai kebutuhan yang telah ditentukan, memastikan kuantitas bahan baku produksi dan Mesin dan peralatan di perusahaan sudah sesuai dengan kebutuhan. Hasil penelitian ini sejalan dengan penelitian yang dilakukan oleh Sakti, (2015) dan Agus (2015), yaitu menganalisis pengaruh manajemen rantai pasokan terhadap proses produksi. Dengan demikian hipotesis ketiga diterima.

\section{KESIMPULAN DAN SARAN}

\section{Kesimpulan}

Berdasarkan hasil penelitian yang dilakukan dan dari pembahasan yang diuraikan diatas, maka dapat diambil kesimpulan sebagai berikut: 1). Terdapat pengaruh positif dan signifikan antara bahan baku dan manajemen rantai pasokan terhadap proses produksi PT. Niro Ceramic Nasional Indonesia. 2). Terdapat pengaruh positif dan signifikan bahan baku terhadap proses produksi PT. Niro Ceramic Nasional Indonesia. 3). Terdapat pengaruh positif dan signifikan manajemen rantai pasokan terhadap proses produksi PT. Niro Ceramic Nasional Indonesia.

\section{Saran}

Sesuai kesimpulan yang telah diuraikan diatas, peneliti memberikan saran diantaranya sebagai berikut: 1). PT. Niro Ceramic Nasional Indonesia, mempertahankan dan meningkatkan bahan baku dan manajemen rantai pasokan secara berkesinambungan agar proses produksi berjalan dengan lancar secara maksimal sehingga mutu atau kualitas dan kuantitas barang yang dihasilkan tetap terjaga dengan baik. 2). PT. Niro Ceramic Nasional Indonesia, maka dimaksimalkan pengawasan dalam pemeriksaan penerimaan bahan baku yang diterima perusahaan dari pemasok sebelum digunakan proses produksi, baik dari segi kualitas maupun kuantitas bahan baku utama. Pihak produksi apabila ada permasalahan dalam kualitas produk yang diterima maka segera dilakukan pencatatan dan segera melapor ke atasan. Dari segi harga bahan baku disarankan PT. Niro Ceramic Nasional Indonesia harga pokok penjualan harus sudah diperhitungkan sesuai dengan yang akan terjadi, dengan memilih pemasok yang memiliki harga cenderung stabil, adapun harga bahan baku mengalami kenaikan di pasar, tetapi kenaikannya tidak mengalami perubahan yang signifikan. 3). PT. Niro Ceramic Nasional Indonesia, lebih di optimalkan tugas dan tanggung jawab dari manajemen rantai pasokan dalam pelaksanaan kegiatan produksi ketepatan pengadaan bahan baku, menjamin lini produksi berfungsi dengan baik sesuai dengan standar operasional perusahaan, dilakukan pengawasan dalam produksi, tersedianya kartu persediaan untuk mendata dan mengetahui jumlah produk yang tersedia di gudang.

\section{DAFTAR PUSTAKA}


Agus, Arawati. 2015. Supply Chain Management: The Influence of SCM on Production Performance and Product Quality. Journal of Economics, Business and Management. DOI: 10.7763/JOEBM 2015.V3.332. Vol. 3. No. 11 November 2015. Malaysia.

Ahyari, Agus. 2012. Manajemen Produksi Perencanaan Sistem Produksi. Yogyakarta: Penerbit BPFE.

Assauri, Sofjan. 2016. Manajemen Operasi Produksi. Jakarta: Penerbit PT. Raja Grafindo Persada.

Gaspersz, Vincent. 2010. Total Quality Management (TQM). Jakarta: Penerbit PT. Gramedia Pustaka Utama.

Gunawan, Cakti Indra. 2016. Teori Dasar Manajemen Produksi dan Operasinal. Cetakan Pertama. Purwokerto: Penerbit CV. IRDH (Research and Publishing) Anggota IKAPI.

Haming, Nurdifin dan Mahfud Nurnajamuddin. 2012. Manajemen Produksi Modern (Operasi Manufaktur dan Jasa). Edisi kedua. Cetakan Pertama. Jakarta: Penerbit: PT. Bumi Aksara.

Handoko, T Hani. 2012. Dasar-Dasar Manajemen Produksi dan Operasi. Edisi Pertama. Cetakan ketujuh belas. Yogyakarta: Penerbit BPFE.

Heizer, Jay dan Barry Render. 2015. Manajemen Operasi (Manajemen Keberlangsungan dan Rantai Pasokan). Edisi 11. Edisi Bahasa Indonesia. Jakarta: Penerbit Salemba Empat.

Herjanto, Eddy. 2010. Manajemen Operasi. Edisi: Revisi. Jakarta: Gramedia.

Irhami, Fahmi. 2014. Manajemen Operasi dan Produksi. Jakarta: Penerbit Alfabeta.

Martono, R. 2015. Manajemen Logistik Terintegrasi. Jakarta: Penerbit: PPM Manajemen.

Ramdhani, A. 2014. Manajemen Operasi. Bandung: Penerbit CV. Pustaka Setia.

Sahaya, Williem. 2013. Sukses Supply Chain Management Akses Demand Chain Management. Jakarta.

Sakti. 2016. Konsep Supply Chain Management (SCM) Pada Proses Produksi Dalam Pengelolaan Persediaan Bahan Baku. Jurnal Teknologi Informasi. Volume 12. Nomor 2. Agustus 2016. ISSN: 1979-1496.

Santoso, Singgih. 2010. Statistik Multivariat. Jakarta: Penerbit PT. Elex Media Komputindo. Sugiyono. 2015. Metode Penelitian (Kualitatif, Kuantitatif, dan R\&D). Cetakan ke-22. Bandung: Penerbit Alfabeta CV.

Sumarsan, Thomas. 2013. System Pengendalian Manajemen. Jakarta: Penerbit PT. Indeks.

Tahwin, Muhammad, A. Aviv Mahmudi, dan Dian Ayu Liana Dewi. 2016. Model Supply Chain Management Dalam Upaya Pengembangan Industri Batik Tulis Lasem Kabupaten Rembang. Fokus Ekonomi. Vol. 11 No. 2 Desember 2016: 1-12. Rembang. Tampubolon, Manahan P. 2014. Manajemen Operasi Dan Pemasok (Operation and Supply Chain Management). Edisi Pertama. Jakarta: Penerbit Mitra Wacana Media.

Widjaja, Tunggal Amin. 2012. Logistic Management \& Supply Chain Management. Jakarta: Penerbit Harvarindo.

Yamit, Zulian. 2011. Manajemen Produksi dan Operasi. Yogyakarta: Penerbit Ekonisia.

Yani, Ari Soeti. 2017. Pengaruh Perencanaan Kebutuhan Bahan Baku Dan Pengawasan Mutu Bahan Baku Terhadap Kelancaran Proses Produksi Pada Industri Otomotif. Jurnal Manajemen. Vol. 13 (2): 85-191, ISSN: 1907-0896.

Zulfahmi, Rizqi Fauzi, Tacbir Hendro Pudjiantoro, Dian Nursantika. 2018. Pembangunan Sistem Manajemen Rantai Pasok Dalam Proses Produksi Minuman Tradisional Di CV. Cihanjuang Inti Teknik. Seminar Nasional Teknologi Informasi dan Multimedia. 10 Februari 2018. ISSN: 2302-3805. Yogyakarta. 
